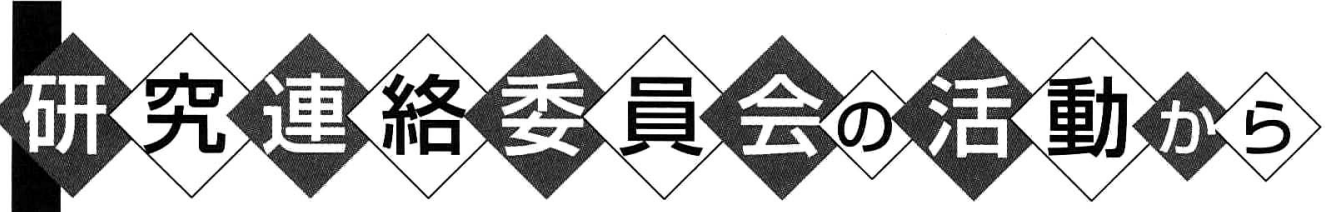

日本学術会議では、

活動計画に基づく審議を各委員会が行うほか、

シンポジウム等の開催を行っています。

このコ一ナーでは、

各研究連絡委員会および專門委員会の活動を、

すでに開催されたシンポジウム等の

開催の状況を交えて紹介いたします。

\section{地質科学と地質技術者 一欧米諸国の現状一}

一地質科学総合研究連絡委員会環境地質学専門委員会の活動 から—

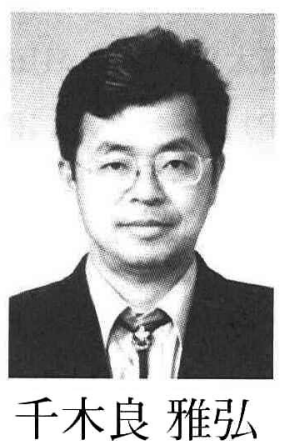

\section{環境地質学とそれを取り巻く状況}

環境地質学は、われわれの足元の地質学であり、 理学であるとともに、工学に近い性格も持ってい る。内閣府が平成15年に実施した「科学技術と社 会に関する世論調査」では、国や公的機関が取り 組もべき科学技術分野のトップ6のうち5 項目は、 すべて環境地質学と密接に関係する内容で占めら れていた。すなわち、地球環境や自然環境の保全、 資源の開発やリサイクル、エネルギーの開発や有 効利用、廃棄物の処理・処分、防災や安全対策で ある。

環境地質学は、まさにわれわれの環境を形作る 地質現象に関する学問分野であり、成果を科学技 術として社会に還元すべき責務を負う面も持って いると言える。この「成果を科学技術として社会
に還元する」ことは、大学などの研究者とともに、 主に理学部で教育を受けた「地質技術者」によって 行われてきたのであるが、それを取り巻く内外の 状況が急激に变化してきているのである。近年技 術者のグローバリゼーションが進み、ワシントン アコード参加国の工学技術者教育プログラム認定 とその相互承認が進み、わが国でも1999年に日本 技術者教育認定機構 (JABEE) が設立され、いく つかの地球科学関係教育プログラムが認定審査を 受けつつあるところである。

\section{「諸外国における地質技術者資格と 教育の実情と我が国におけるあり方」 シンポジウム}

当専門委員会では、地質技術者の資格と教育の 最適なあり方を検討し、実現することが、地質科 
学の発展と持続可能な社会の実現に不可欠である と認識し、それを重点課題の 1 つと位置づけてい る。その活動の一環として、平成15年12月25日に は、「諸外国における地質技術者資格と教育の実 情と我が国におけるあり方」と題したシンポジウ ムを開催し、討論を行った。主催者には、地質学 研究連絡委員会、資源開発工学研究連絡委員会、 日本応用地質学会、日本地質学会、日本地下水学 会、資源・素材学会にも加わっていただいた。

約60名の参加を得て、1）JABEE（日本技術者教 育認定機構) の状況、2) 技術者資格 (欧米、米国、 カナダ、英国、オーストラリア)、3）地質技術者 教育 (米国、英国、カナダ、オーストラリア、ニ ユージーランド)、4）我が国の地質技術者教育の ありかた、について、報告・討論を行った。

\section{欧米における地質技術者の資格と教育}

地質技術者の教育と技術者資格の調査の結果、 色々な科学技術の分野の中にあって地質関連の分 野はかなり特殊なものであることが浮かび上がっ てきた。すなわち、大学のプログラムを見ると、 化学や物理、生物には、それぞれ工学の分野の中 に工業化学、応用物理、生物工学などのプログラ ムがあるが、地質工学といったプログラムはかな り限られた数になってしまう。米国で17プログラ

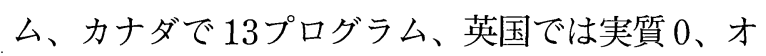
ーストラリアで1プログラムである。わが国では、 今のところ1 2のプログラムといったところであ ろうか。

技術者資格について見ると、調查対象としたす べての国で工学技術者 (いわゆるProfessional Engineer)のほかに地質技術（あるいは地球科学技 術)に特化した技術者資格 (Professional Geologist など）を有していることが明確になった。工学技 術者と狭義の地質技術者との違いは、大まかに言 えば、前者はエンジニアリングを行うことに法的 根拠が与えられた技術者資格であり、後者は、地
下の状況を調査したり、地球科学の原理を技術的 に適用したりすることに法的根拠が与えられた技 術者資格である。色々な科学分野がある中で、特 定技術者資格として多くの国に認められている分 野としての資格は、この地質技術者だけであろう。

わが国の場合、地質技術者として明示はされて いないが、技術士の中の応用理学部門 (地質) がそ れに相当する。 4 万人の技術士の中で約 2000 人の地 質技術者が活躍している。このような独立した地 質技術者資格の存在は、おそらく地質学あるいは 地球科学の特殊性一つまり、国土の基本的な科学 であることーと関係あるのではないかと思える。

\section{地質技術者の相互認定の流れ}

上述したように、地質技術者資格を多くの国が 有しているが、さらに、これらの資格認定機関同 士が相互に認定しあう流れが進んでいる。 European Federation of Geologists、Canadian Council of Professional Geoscientists (CCPG/CCGP) , American Institute of Professional Geologists (AIPG), National Association of State Boards of Geology (ASBOG), Australian Institute of Geoscientists (AIG) などの組織が、急速に相 互認定のための覚書を交わし始めていることが明 確になってきた。これらの覚書は、まだ、相互の 組織を認める、といった程度のものであり、強い 拘束力はないが、前述した工学技術者資格の相互 認定の動きに追随するものとも考えられる。

先進国の中で最も地殻変動が激しく,地質構造も 複雑な日本がこうした技術者資格の認定、さらに は、技術者教育認定のリーダーシップをとるべき 時だと考えられる。

千木良 雅弘（ちぎら まさひろ 1955年生）

日本学術会議地質科学総合研究連絡委員会、環境地質学専門委 員会委員長、京都大学教授（防災研究所）

専門：応用地質学 